\title{
Field data collection and analysis of canopy and litter interception in commercial forest plantations in the KwaZulu-Natal Midlands, South Africa
}

\author{
H. H. Bulcock and G. P. W. Jewitt \\ School of Agriculture, Earth and Environmental Science, University of KwaZulu-Natal, Private Bag X01, \\ Scottsville, 3209, South Africa \\ Correspondence to: H. H. Bulcock (bulcockh@ukzn.ac.za)
}

Received: 25 May 2012 - Published in Hydrol. Earth Syst. Sci. Discuss.: 5 July 2012

Revised: 11 September 2012 - Accepted: 17 September 2012 - Published: 19 October 2012

\begin{abstract}
It is well accepted that the total evaporation in forested areas is greater than in grasslands, largely due to the differences in the amount of rainfall that is intercepted by the forest canopy and litter and due to higher transpiration rates. However, interception is the least studied of these components of the hydrological cycle. The study aims to measure and quantify the canopy and litter interception by Eucalyptus grandis, Pinus patula and Acacia mearnsii, at the Two Streams research catchment in the KwaZulu-Natal Midlands of South Africa for the three-year period April 2008 to March 2011. The results from this study showed that canopy and litter interception contributed a significant amount of the water evaporated in a forest water balance. The canopy interception by E. grandis, A. mearnsii and $P$. patula was $14.9 \%, 27.7 \%$ and $21.4 \%$ of gross precipitation, respectively, while litter interception was $8.5 \%, 6.6 \%$ and $12.1 \%$ of gross precipitation, respectively.
\end{abstract}

\section{Introduction}

It is well accepted that total evaporation in forested areas is larger than in grasslands, mainly due to the large amount of rainfall that is intercepted by the forest canopy (Bosch and Hewlett, 1982) and litter and due to higher transpiration rates. Although rainfall interception and transpiration by the tree canopies are responsible for most of the transfer of water and energy, a smaller but significant role is played by the forest floor litter interception (Schaap and Bouten, 1997; Gerrits, 2010). In some cases, half or more of the forest's total evaporation originates from these processes, viz. canopy and litter interception (Schaap and Bouten, 1997). This fraction of water is not available to the soil and thus modifies the balance of water and energy at the Soil-Vegetation-Atmosphere (SVAT) interface (Cuartus et al., 2007). It can be said that interception is a threshold process, as a certain amount of precipitation is required to saturate the canopy as well as the litter storage capacity deficit before successive processes can take place.

The amount of canopy interception depends on climatic factors, such as the rainfall characteristics, as well as factors affecting evaporation, including temperature, wind speed, solar radiation and humidity. Climatic factors play a vital role in determining the amount of water that is intercepted. In most areas of the world there are large variations in the characteristics of rainfall within and between seasons. These climatic conditions are important both during and after a rainfall event (Llorens et al., 1997). Evaporation during the event may comprise a substantial portion of the total amount of water evaporated (Crockford and Richardson, 1990, 2000). Water stored in forest canopies has been found to evaporate at rates in excess of potential evaporation due to advection and low aerodynamic resistance of wet canopies (David et al., 2005). The amount, intensity and duration of rainfall also play a vital role in determining the amount of interception.

Vegetation characteristics also play a vital role in determining the amount of rainfall intercepted. The storage capacity of the vegetation depends on the shape, orientation, density (leaf area index) and hydrophobicity of the leaves and branches (David et al., 2005). In this study, 
broad-leaf, needle-leaf and compound-leaf canopies were studied. Different trees with the same leaf area index (LAI) may have very different storage capacities, depending on their leaf/canopy characteristics. Another important factor is whether the vegetation is deciduous or evergreen, as deciduous trees lose their leaves during the winter. In commercial forests, the age, planting density and management practices, such as whether the stand is thinned or pruned, will also affect the canopy interception.

Although interception and transpiration by the canopy is responsible for most of the transfer of water and energy, a smaller though significant role is played by litter interception (Schaap and Bouten, 1997; Gerrits, 2010). Litter interception is a function of litter mass per unit area, thickness and composition, its water holding characteristics, wetting frequency, and rate of drying. The thickness and composition of the litter varies during the seasons and from one location to the other, due to different characteristic cycling of litterfall and decomposition (Park et al., 1998). In this study, the litter of each of the three genera has very different characteristics.

The processes of canopy and litter interception are however often not considered as significant processes in the hydrological cycle (Gerrits et al., 2006) and therefore not often studied. In addition, the difficulties inherent in interception measurements (Llorens and Gallart, 2000) may add to the reluctance of some researchers to address the role of interception fully. In South Africa, few studies of interception in forested areas have been undertaken and those that do exist are limited in their scope and wider applicability. In a study by Dye and Versfeld (1992) on a ten-year-old Pinus patula stand it was found that the canopy interception was $14.8 \%$ of gross precipitation. Versfeld (1987) measured canopy interception losses of $10.8 \%$ of gross precipitation for Pinus radiata. However, there have been studies that have found canopy interception in a Pinus sylvestris as high as $42.2 \%$ of gross precipitation in Scotland (Gash et al., 1980). Dye and Versfeld (1992) found canopy interception by four-yearold Eucalyptus grandis to be as low as $6 \%$ of gross precipitation. Langford and O'Shaughnessy (1978) measured canopy interception losses of $23.3 \%$ of gross precipitation in a stand of Eucalyptus regnans in Melbourne, Australia. The only canopy interception results for Acacia mearnsii in South Africa are by Everson et al. (2006), who suggest that it is greater than $20 \%$ of gross precipitation, while Samraj et al. (1982) found canopy interception by A. mearnsii to be $25 \%$ in Nilgiris, India. More recently, Tsiko et al. (2012) found canopy interception in a savannah ecosystem in Zimbabwe to be $25 \%$ of gross precipitation. There have been even fewer litter interception studies in South Africa. Jacobz (1987) found litter interception in fifteen-year-old Pinus patula and Pinus radiata to be $16 \%$ and $32 \%$ respectively. Jewitt (1991) measured litter interception in four- and eightyear-old Eucalyptus grandis and four-year-old Pinus patula. The results were a loss of $5.7 \%, 9.0 \%$ and $10.1 \%$ respectively. These results were, however, obtained from just 18 events. There have been no documented litter interception studies for Acacia mearnsii.

In 2007, Forestry South Africa (Godsmark, 2008) estimated that approximately $1.1 \%$ of South Africa was under plantation forestry, an area of $1351402 \mathrm{ha}$, the majority of which is located in the higher-rainfall eastern and southern regions of the country. These plantations comprise $53.5 \%$ pine, $37.7 \%$ eucalyptus, $8.1 \%$ wattle and $0.7 \%$ "other". Given that commercial forestry is a licensed water user and that users have to pay for this use, it is important that water use, including interception, is accurately quantified. Thus, this study aimed to measure and quantify the canopy and litter interception for typical sites of the three most common commercial forestry genera in South Africa, viz. Eucalyptus, Pinus and Acacia.

\section{Materials and method}

\subsection{Site description}

The study took place between April 2008 and the end of March 2011 on the Mondi Forests Mistley-Canema estate $\left(30.67^{\circ} \mathrm{S}, 29.19^{\circ} \mathrm{E}\right)$, which is situated in the Seven Oaks district, about $70 \mathrm{~km}$ northeast of Pietermaritzburg in the KwaZulu-Natal Midlands, South Africa, as shown in Fig. 1. The site is classified as "Moist Midlands Mistbelt" according to the South African Bioresource Group (BRG) classification system (Camp, 1997) and "Midlands Mistbelt Grassland" by Mucina and Rutherford (2006). The climate is humid, with an annual rainfall ranging from $800 \mathrm{~mm}$ to $1280 \mathrm{~mm}$ per annum, most of which falls during the summer months between October and March. The summer rainfall is characterised by some high-intensity storms as well as many low-intensity events. During the winter months there are occasional lowintensity frontal systems during this otherwise dry and often windy period. Additional moisture is provided by heavy mists, which are a common feature. The mean annual temperature is $17^{\circ} \mathrm{C}$. Prior to afforestation, the natural vegetation of the area was Themeda triandra grassland (Camp, 1997; Mucina and Rutherford, 2006). Only a few relic patches of Themeda triandra grassland remain, as the high potential of the arable areas has meant that little value has been placed on the natural vegetation. Commercial afforestation has been practiced in the area for a long time and is the most widespread land use, with gum (Eucalyptus), pine (Pinus) and wattle (Acacia) being the genera of choice. Sugarcane is also grown at sites where drainage of cold air is good, ensuring that no frost or only light frost occurs (Everson et al., 2006). Experiments were set up at three sites within the estate for each of the three commercial forestry species and compliment an existing long-term water balance experiment. The study sites are shown in Fig. 1 and the co-ordinates and elevation of the study sites are shown in Table 1. 
Table 1. Co-ordinates of the study sites on the Mistley-Canema estate.

\begin{tabular}{lrrr}
\hline Site description & Latitude (S) & Longitude (E) & $\begin{array}{r}\text { Elevation } \\
\text { (m a.s.l) }\end{array}$ \\
\hline E. grandis & $29^{\circ} 12^{\prime} 19.4^{\prime \prime}$ & $30^{\circ} 39^{\prime} 12.5^{\prime \prime}$ & 1069 \\
A. mearnsii & $29^{\circ} 12^{\prime} 19.4^{\prime \prime}$ & $30^{\circ} 39^{\prime} 02.1^{\prime \prime}$ & 1095 \\
$P$. patula & $29^{\circ} 11^{\prime} 06.4^{\prime \prime}$ & $30^{\circ} 39^{\prime} 16.4^{\prime \prime}$ & 1065 \\
Automatic Weather Station & $29^{\circ} 11^{\prime} 47.8^{\prime \prime}$ & $30^{\circ} 39^{\prime} 58.4^{\prime \prime}$ & 1098 \\
Above-canopy AWS & $29^{\circ} 12^{\prime} 19.4^{\prime \prime}$ & $30^{\circ} 39^{\prime} 12.5^{\prime \prime}$ & 1070 \\
\hline
\end{tabular}

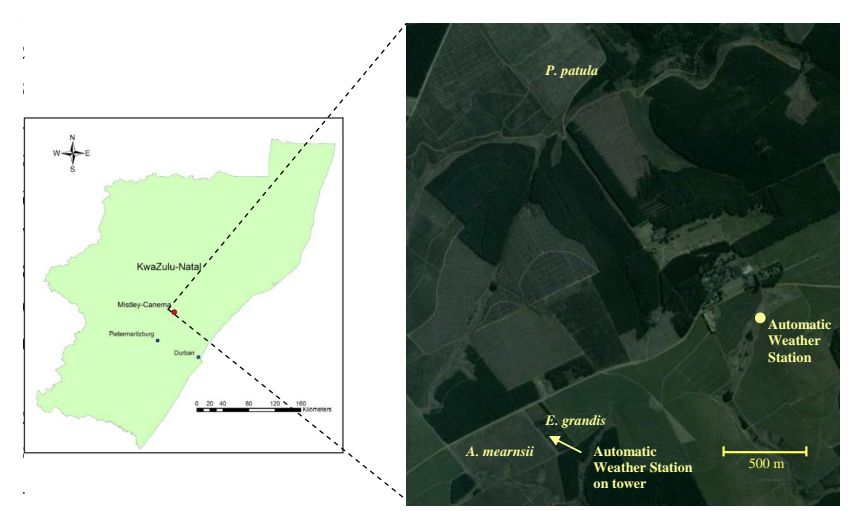

Fig. 1. Location of Mistley-Canema estate in KwaZulu-Natal, South Africa (Google Earth, 2009).

\subsection{Forest stand description}

In this study, canopy and litter interception for typical sites of the three most common commercial forestry genera in South Africa, viz. Eucalyptus, Acacia and Pinus, were measured. Eucalypts are usually planted at 1666 spha (stems per hectare) and clear-felled at 7 to $10 \mathrm{yr}$ of age. The Eucalyptus stand used in this study was planted at 1600 spha and was $5 \mathrm{yr}$ of age. Pines are usually planted at a density of 1111 spha for sawtimber and up to 1736 spha for pulpwood. Pulpwood stands, such as the stand used in this study, are usually felled at between 15 and $18 \mathrm{yr}$, while sawlogs have a longer rotation and are felled at between 20 and $30 \mathrm{yr}$. As the pine stand used in this study was planted for pulpwood, the planting density of 1600 spha is typical. Acacia mearnsii are primarily used for their high tannin content in the bark, but are also used for pulping. Acacia mearnsii are usually grown at a density of approximately 1500 spha and felled at between 8 and $12 \mathrm{yr}$ (Zwolinski and Bayley, 2001). The Acacia mearnsii stand used in this study was planted at a lower density than usual at 1111 spha. The characteristics of the forest stands are summarised in Table 2.

\subsection{Weather data}

Gross precipitation and reference evaporation data were supplied by the Council for Scientific and Industrial Research (CSIR) from two automatic weather stations forming part of the ongoing Water Research Commission (WRC) project. An "energy balance" weather station was situated between the A. mearnsii and E. grandis sites and was mounted on a tower above the canopy. It is termed an "energy balance" weather station because it includes net radiation and soil heat flux, which are not included on a standard weather station. A Campbell Scientific CR10x logger at the automatic weather station, which measures all the parameters required to calculate Penman-Monteith reference evaporation, was programmed to calculate the reference evaporation. It was situated approximately $1.7 \mathrm{~km}$ from the $P$. patula site in an open kikuyu grassland. The automatic weather station measured solar irradiance $\left(\mathrm{W} \mathrm{m}^{-2}\right)$, ambient temperature $\left({ }^{\circ} \mathrm{C}\right)$, relative humidity $(\%)$, rainfall $(\mathrm{mm})$, windspeed $\left(\mathrm{m} \mathrm{s}^{-1}\right)$ and direction $\left({ }^{\circ}\right)$ at 10-min, 20-min and hourly intervals and calculated reference evaporation hourly and daily. The energy balance automatic weather station located on the tower measured net irradiance $\left(\mathrm{W} \mathrm{m}^{-2}\right)$, air temperature $\left({ }^{\circ} \mathrm{C}\right)$, relative humidity $(\%)$, rainfall $(\mathrm{mm})$, windspeed $\left(\mathrm{m} \mathrm{s}^{-1}\right)$ and direction $\left({ }^{\circ}\right)$, soil temperature $\left({ }^{\circ} \mathrm{C}\right)$ at $20 \mathrm{~mm}$ and $60 \mathrm{~mm}$, and soil heat flux at $80 \mathrm{~mm}\left(\mathrm{~W} \mathrm{~m}^{-2}\right)$ at 10-min, 20-min and hourly intervals (Clulow, 2007).

The historic rainfall record from September 1998 to March 2011 as well as the rainfall during the study period from April 2008 to March 2011 are illustrated in Fig. 2. Both periods show a similar rainfall distribution, indicating that the study period was typical in terms of rainfall. The high percentage of "small" events is noticeable. In this study, rainfall events are defined as discrete events separated by a period greater than one hour. Rainfall events of less than $1 \mathrm{~mm}$ account for $50.8 \%$ of the events during the study period. The events below $4.0 \mathrm{~mm}$ account for approximately $73.6 \%$ of all the rainfall events during the study period. This is significant because during these "small" events, it is likely that most of the rainfall will be intercepted by the canopy and the litter, depending on the antecedent canopy and litter moisture content.

\subsection{Canopy interception measurements}

Throughfall measurements were made using a nest of three "V"-shaped troughs at each site, constructed from galvanised iron sheeting (Fig. 3) based on the design of Cuartus et al. (2007). The dimensions of each trough were 
Table 2. Summary of forest stand characteristics for the study sites at Two Streams as of March 2011.

\begin{tabular}{|c|c|c|c|c|c|c|c|c|}
\hline $\begin{array}{l}\text { Species and } \\
\text { compartment } \\
\text { number }\end{array}$ & $\begin{array}{l}\text { Age } \\
(\mathrm{yrs})\end{array}$ & $\begin{array}{r}\text { Height } \\
(\mathrm{m})\end{array}$ & $\begin{array}{r}\text { Mean diameter } \\
\text { at breast } \\
\text { height }(\mathrm{cm})\end{array}$ & $\begin{array}{r}\text { Planting } \\
\text { density } \\
\text { (spha) }\end{array}$ & $\begin{array}{l}\text { Management } \\
\text { practice }\end{array}$ & $\begin{array}{r}\text { Max } \\
\text { LAI }\end{array}$ & $\begin{array}{r}\text { Average } \\
\text { litter } \\
\text { thickness } \\
(\mathrm{mm})\end{array}$ & $\begin{array}{r}\text { Litter } \\
\text { mass/unit } \\
\text { area } \\
\left(\mathrm{kg} \mathrm{m}^{-2}\right)\end{array}$ \\
\hline E. grandis $(\mathrm{T} 005 \mathrm{~A})$ & 5 & 14.3 & 15.2 & 1600 & Pruned & 2.7 & 38 & 2.32 \\
\hline A. mearnsii $(\mathrm{C} 005)$ & 5 & 13.6 & 13.5 & 1111 & Thinned and pruned & 2.3 & 20 & 2.40 \\
\hline P. patula (B053) & 16 & 16.1 & 28.4 & 1600 & Thinned and pruned & 1.9 & 97 & 3.34 \\
\hline
\end{tabular}

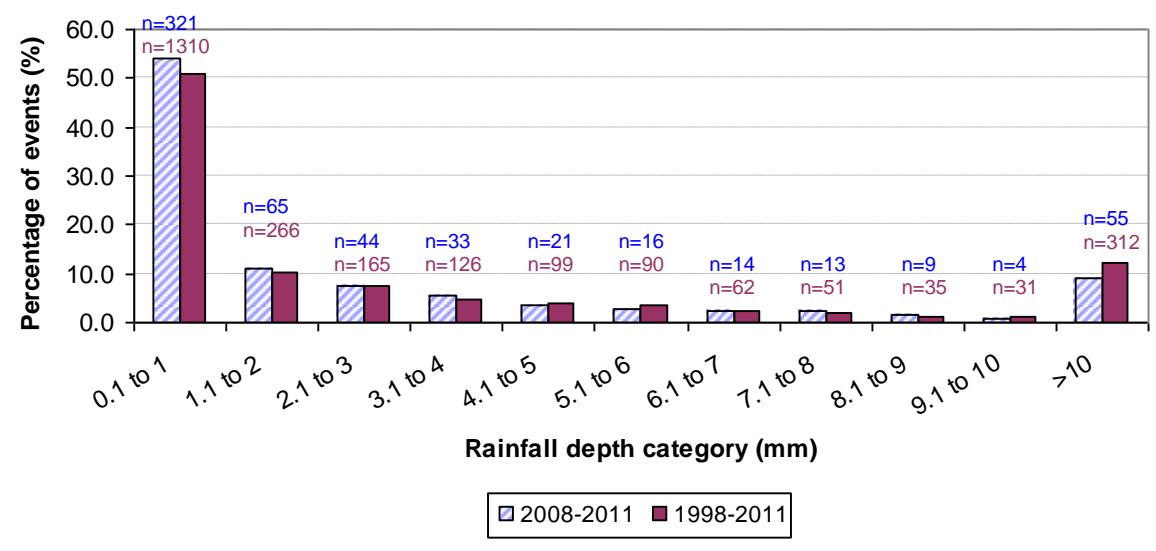

Fig. 2. Percentage of rainfall events per rainfall depth category $(n=595$ and $n=2577)$.

$0.1 \mathrm{~m}$ wide $\times 2.0 \mathrm{~m}$ long. Conventional "U"- or "V"-shaped troughs are susceptible to blockage by fallen debris and water loss from splash-out, however, this system minimises splashout by using steep "V"-shaped sides. The troughs were covered with mosquito netting to minimise the entry of debris, which reduced the demand of cleaning and maintaining the system. A correction factor for each trough was derived from laboratory measurements to account for the "initial abstraction" from the netting. The three troughs were then connected to a single tipping bucket gauge and an event data logger. Because the trough represents a linear and continuous sampling surface, the linear variation of leaves, branches, and tree crown, the throughfall it catches, was assumed to be a representative integral of throughfall. A shortcoming of the throughfall troughs was that they were still susceptible to occasional blockages ( 8 out of 595 events, i.e. $1.3 \%$ ) during large rainfall events, particularly at the A. mearnsii site, which has very small compound leaves that were still able to fit through the netting. From field observations and analysis of the raw data, such events were patched using a regression analysis. One nest of three troughs was decided to be sufficient, due to the uniform spacing of the trees in the plantation. Also, the radial arrangement of the three troughs accounts for the radial variability of throughfall from the trunk to the edge of the canopy. A similar sampling strategy was used by Cuartus et al. (2007).

\subsection{Leaf area index measurements}

The LI-COR LAI-2000 plant canopy analyzer (LAI-2000, LI-COR, Inc., Lincoln, Nebraska, USA) was used to measure the plantation forest's single-sided LAI. Due to the height of the trees, it was not possible to take measurements above the canopy. Thus the "remote mode" method was used, i.e. two control units are used to log the above- and below-canopy readings simultaneously. Ten sets of four readings were taken for each plot, each point being taken at random points and orientations beneath the canopy. At the same time, a separate synchronised instrument was located in an open area and took readings every $15 \mathrm{~s}$, representing the above-canopy readings. Light readings made below the canopy are divided by readings made above the canopy to compute transmittances at five angles. A control unit records these readings and calculates LAI from the transmittances (Clulow, 2007). During the data processing stage, the above- and belowcanopy readings were compared to determine the fraction of light transmitted or absorbed by the canopy. A sunlit canopy was avoided by taking readings just before sunset when the solar elevation is low (below $45^{\circ}$ ). A $45^{\circ}$ view restrictor was used to block the sensor in the field of view of the operator. This procedure was followed for all sites, and values are shown in Table 2. One problem that was not accounted for is that the LI-COR LAI-2000 was shown by Gower and Norman (1990) to underestimate LAI in conifer stands by $35-40 \%$. This is due to the fact that the instrument senses 


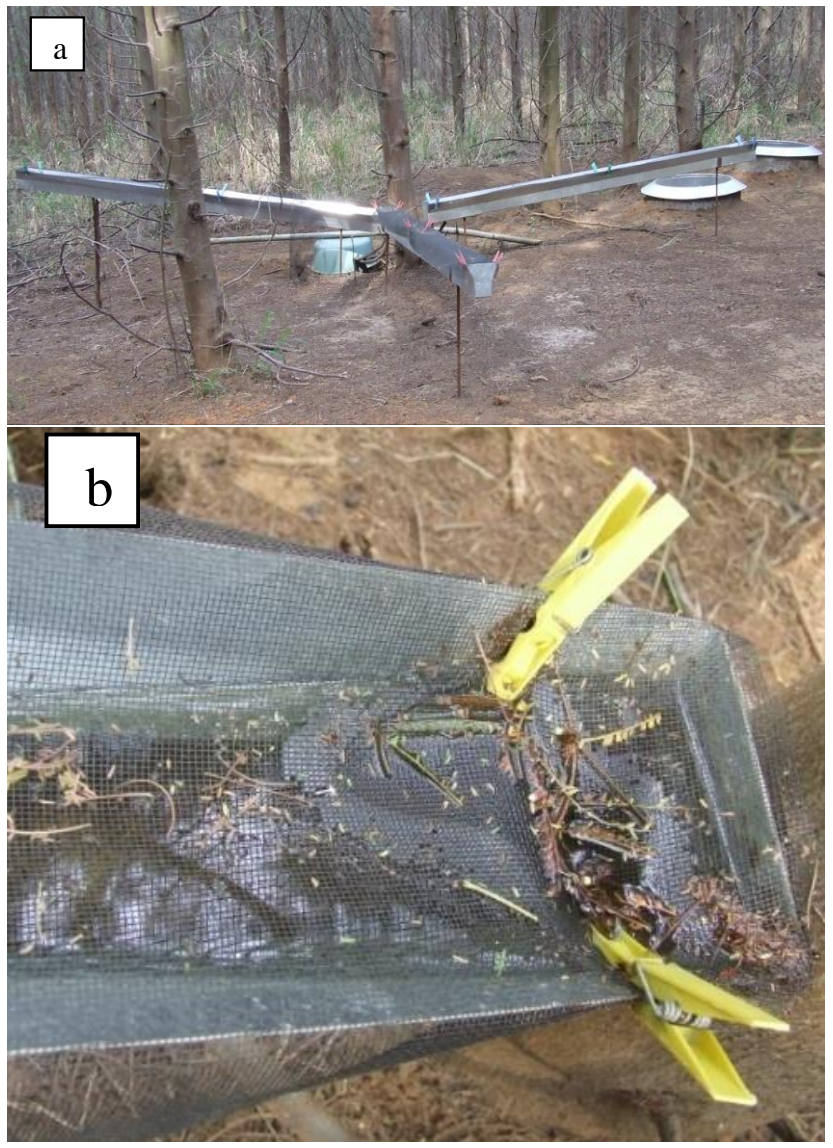

Fig. 3. (a) Throughfall troughs with mosquito netting covering. (b) Showing the blockage of a trough.

projected area of shoots, rather than needles. They found that a correction factor based on the shoot morphology can be applied. This can be independently measured and appears to adequately compensate for this. Their suggested technique is to determine the ratio of projected shoot area to total needle area for the particular species being measured, and then multiply the results by this ratio.

\subsection{Litter interception and water that drains to soil}

The experiment layout for measuring litter interception and water that drains to the soil is shown in Fig. $4 a$, b and c. The litter interception and water that drains to the soil were measured using two round galvanised iron basins that fit into each other. Two litter interception basins were placed at each site to account for the spatial variability of the litter thickness. The upper basin, which had an inner diameter of $0.5 \mathrm{~m}$, was filled with litter and had a geotextile lining on top of a wire mesh base, so that water could percolate into the lower basin, but the fine particles from the litter are retained. A flat spade was used to slide under the litter at the littersoil interface as carefully as possible so as to limit the disturbance of the sample. This sample was then placed into

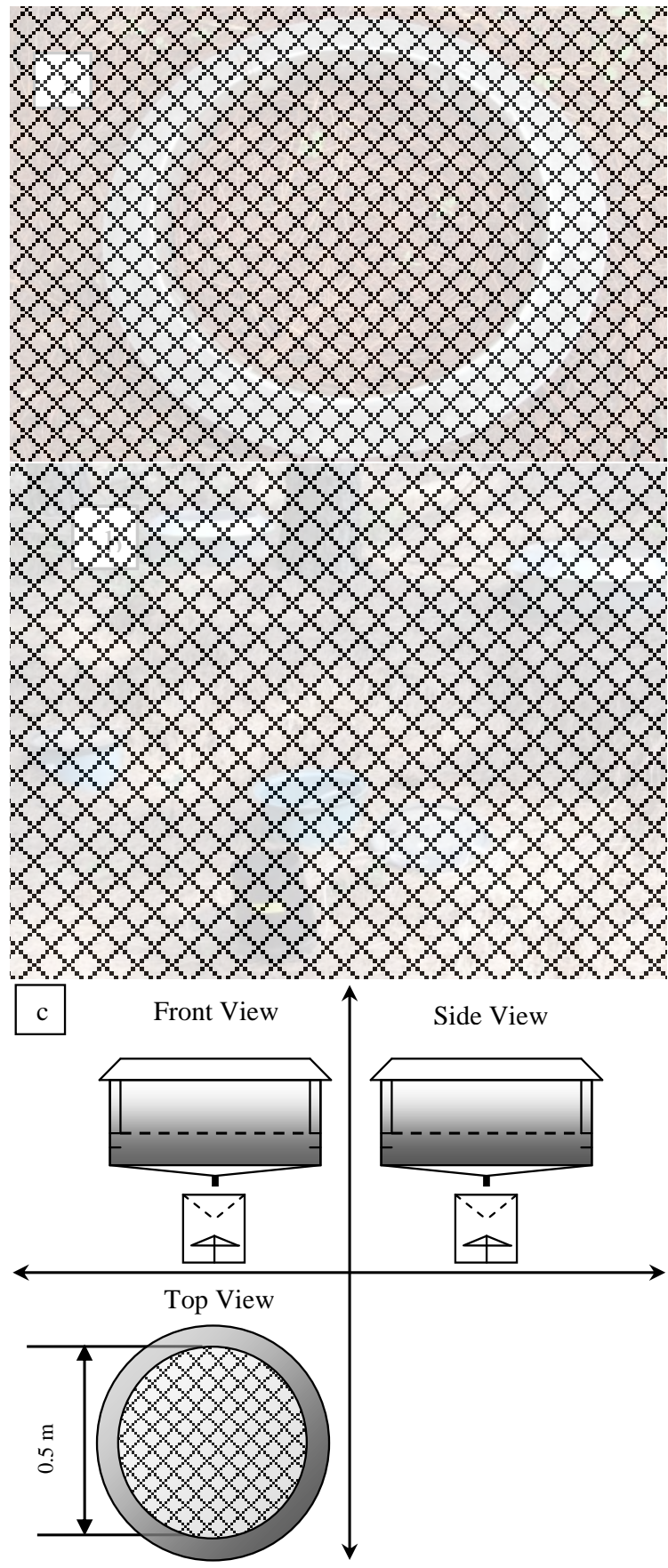

Fig. 4. (a) Top view of litter interception equipment. (b) Litter interception equipment and tipping bucket raingauge that is housed in the blue buckets. (c) Schematic of litter interception equipment and tipping bucket.

the interception basin. The water that was collected in the lower basin, which is the water that would have drained to the soil, is measured with a Davis tipping bucket (Davis Instruments, 2001) and each tip was recorded with a HOBO pendant event logger (Onset Computer Corporation, 2005). The litter interception is then calculated as the difference 
between throughfall measurements obtained and the water that drained to the soil. The experiment was replicated twice at each of the three sites.

\subsection{Possible errors in litter interception measurements}

Litter interception is not well studied, and for good reason. One reason is that it is not easy to measure. There are a number of potential errors that may influence the litter interception results. Inherent in many field experimental setups is the disturbance of the system, leading to possible errors. One such error arises from transferring the litter from the forest floor to the interception basin, where the sample may not be compacted to the same density, thickness or composition as it was on the forest floor. Similarly, by removing the sample from the forest floor, the interaction between the forest floor soil and the litter is lost, and water that enters the litter ought not to be considered as an entirely separate store from soil water. This is highlighted by Schaap and Bouten (1997), who modelled the forest floor litter moisture content dynamics as another "soil" layer, using a physically based model. It is also often very difficult to define the boundary between the humus layer (H-layer) and the $A_{1}$-layer where the organic matter and mineral soil are incorporated. Furthermore, fine roots in the litter from the trees or understorey vegetation are no longer able to access the water in the litter. Another potential error is introduced by the use of geotextile or any other artificial barrier. It has been noted by Helvey and Patric (1965) and Gerrits (2010) that the geotextile may cause water accumulation on the interface before drainage starts. A further error may be introduced due to the fact that the litter interception basins are positioned approximately $10 \mathrm{~cm}$ above the ground. This can alter the wind flow, causing turbulence and therefore potentially increasing the evaporation. In this study, the wind effect was minimised by having angled sides on the rim of the litter interception basins, making them more aerodynamic, as can be seen in Fig. 4. However, the windspeed under the canopy is very low, and therefore the effect of wind under the canopy is significantly reduced. Gerrits (2010) used a similar system to the one used in this research, where one basin is suspended above another. However, the system used by Gerrits (2010) attempted to measure litter interception directly by using strain gauge sensors to measure the change in mass of the top basin. This change in mass could then be used to calculate the evaporation from the litter. This method did however also have many potential sources of error. The main source of error was due to the strain gauges being sensitive to temperature, which Gerrits (2010) attempted to correct by using a so-called "dummy sensor" to compensate for the influence of temperature. In an environment with high temperatures such as in South Africa, it was decided that this system would not be used.
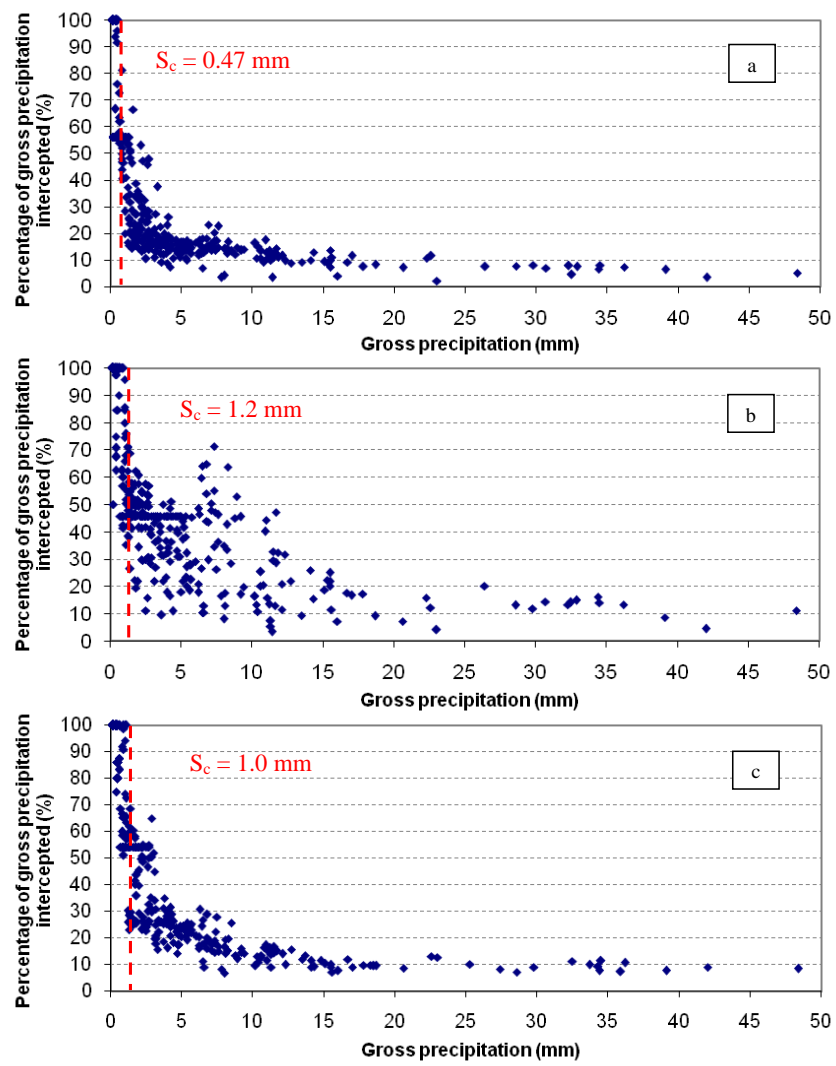

Fig. 5. Percentage of gross precipitation intercepted by the canopy of (a) Eucalyptus grandis, (b) Acacia mearnsii and (c) Pinus patula $(n=565)$. The canopy storage capacity $\left(S_{\mathrm{c}}\right)$ is indicated by the red line.

\section{Results}

The observed results of this study are presented for the period April 2008 to March 2011, with canopy interception, canopy storage capacity, litter interception and the amount of water that drains to the soil for E. grandis, A. mearnsii and P. patula being the foci.

\subsection{Canopy interception and storage capacity}

The relationships between gross precipitation and canopy interception as a percentage of gross precipitation is illustrated in Fig. 5a, b and c. Canopy interception results are often represented as a percentage of gross precipitation as a means to estimate the canopy storage capacity. The maximum amount of gross precipitation to be totally intercepted by the canopy before throughfall takes place is the canopy storage capacity as illustrated by the broken red line in Fig. 5a, b and c. The storage capacity was estimated by analysing the data for the highest rainfall event to result in complete $(100 \%)$ interception. Despite many studies using this method, it is, however, a simplistic method of estimating canopy storage capacity and not necessarily accurate. Alternatively, using the "mean 

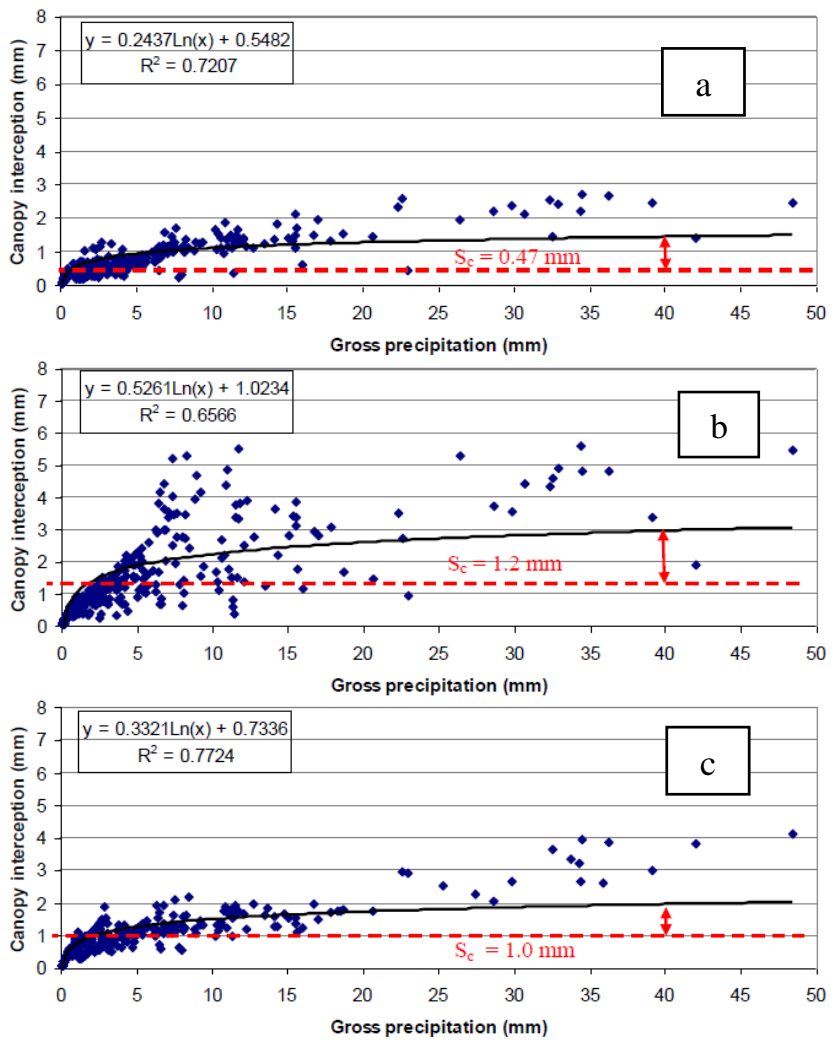

Fig. 6. Canopy interception by (a) Eucalyptus grandis, (b) Acacia mearnsii and (c) Pinus patula $(n=565)$ at Two Streams.

method" of Klaasens et al. (1998) to estimate the canopy storage capacity, only those events that were separated by at least one day of no rainfall were used in the analysis to try eliminating the possibility of a partially wetted canopy. The Klaasens et al. (1998) "mean method" estimates the canopy storage capacity as the y-intercept of the linear regression line of gross rainfall and interception. Using the Klaasens et al. (1998) "mean method", the maximum storage capacities for E. grandis, A. mearnsii and P. patula were $0.41 \mathrm{~mm}$, $1.07 \mathrm{~mm}$ and $0.92 \mathrm{~mm}$ respectively.

The canopy storage capacity for E. grandis, A. mearnsii and $P$. patula is illustrated by the broken red line in Fig. 5a, b and c respectively. It was found that $E$. grandis had a canopy storage capacity of $0.47 \mathrm{~mm}$, which was the lowest of the three species investigated in this study, although it had the highest LAI of 2.7. The storage capacity for A. mearnsii was found to be $1.2 \mathrm{~mm}$ and for $P$. patula was $1.0 \mathrm{~mm}$. Acacia mearnsii and P. patula had LAI's of 2.3 and 1.9 respectively.

The relationship between gross precipitation and canopy interception for E. grandis, A. mearnsii and P. patula is illustrated in Fig. 6a, b and c respectively, from the field measurements for each event obtained at Two Streams from April 2008 to March 2011.

The storage capacity is an important parameter to estimate when considering that interception is a threshold process, and
Table 3. Total observed canopy interception from April 2008 to March 2011.

\begin{tabular}{lrrr}
\hline Species & $\begin{array}{r}\text { Gross } \\
\text { precipitation } \\
(\mathrm{mm})\end{array}$ & $\begin{array}{r}\text { Observed } \\
\text { canopy } \\
\text { interception } \\
(\mathrm{mm})\end{array}$ & $\begin{array}{r}\text { Observed } \\
\text { canopy } \\
\text { interception } \\
(\%)\end{array}$ \\
\hline E. grandis & 1884.7 & 280.4 & 14.9 \\
A. mearnsii & 1884.7 & 522.4 & 27.7 \\
P. patula & 1909.7 & 408.7 & 21.4 \\
\hline
\end{tabular}

only once the storage capacity has been reached do most of the throughfall and subsequent hydrological processes take place, although there is a small amount of direct throughfall before the storage capacity is reached. It can be seen in Fig. $6 a, b$ and $c$ that there are a few events that are less than the storage capacity, where there is not $100 \%$ interception. This may be attributed to consecutive rainfall events taking place before the canopy has had sufficient time to dry out completely, thereby effectively decreasing the canopy storage capacity.

The logarithmic relationship between gross precipitation and canopy interception that can also be found in this study is consistent with other research undertaken in South Africa, such as that done by Schulze et al. (1978) on a Pinus patula stand at Cathedral Peak in KwaZulu-Natal. Although the log function may not fit the data very well, it does illustrate the fact that there is still wet canopy evaporation after the storage capacity of the canopy has been reached due to the fact that evaporation continues during the event, as illustrated by the arrows. Thus, the longer the event lasts, the more wet canopy evaporation will occur and therefore the line fitted to the data does not "flatten" completely. If there was no wet canopy evaporation, then interception would be equal to the storage capacity. The results of the total canopy interception during the study period for $E$. grandis, A. mearnsii and P. patula are presented in Table 3.

The higher-than-expected canopy interception result can be partly attributed to the high percentage $(61.2 \%)$ of rainfall events of less than $2 \mathrm{~mm}$, where almost $100 \%$ of the precipitation is intercepted. This is important because the canopy storage capacity was also found to vary with the intensity of the rainfall event as shown in Fig. 7.

By analysing the gross precipitation and throughfall data, which were recorded at 10-min and "per tip" time steps, respectively, the rainfall intensity and storage capacity could be estimated accurately. This was done by isolating as short a period after saturation as possible, so that wet canopy evaporation was minimised to estimate the canopy storage capacity by subtracting the throughfall from the gross precipitation. The rainfall intensity and storage capacity could therefore be calculated. As shown in Fig. 7, it was found that lowintensity events resulted in a higher canopy storage capacity than high-intensity events. These results are corroborated by 


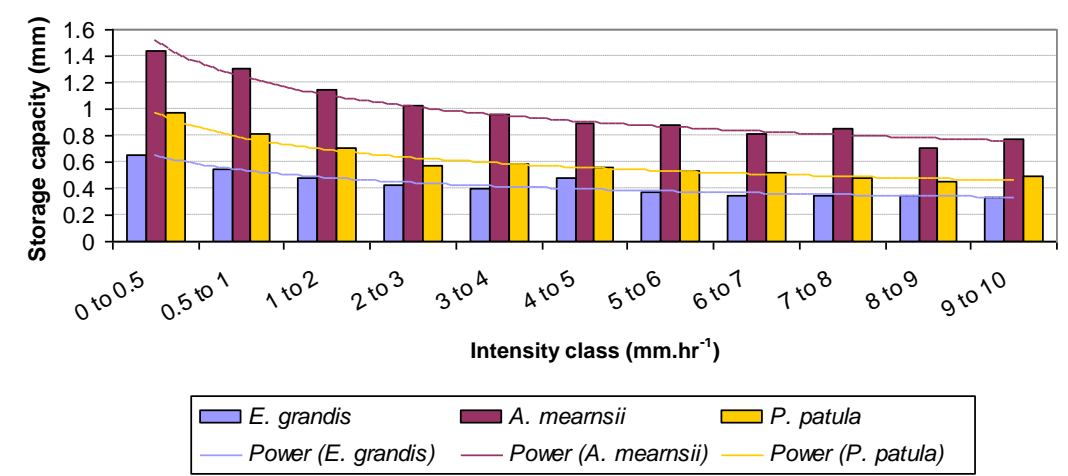

Fig. 7. Canopy storage capacity for E. grandis, A. mearnsii and P. patula at different rainfall intensities.

Table 4. Storage capacity $\left(S_{\mathrm{c}}\right)$ ranges and trendline equations for $E$. grandis, A. mearnsii and $P$. patula, where $x$ is the rainfall intensity $\left(\mathrm{mm} \mathrm{h}^{-1}\right)$.

\begin{tabular}{lrr}
\hline Genus & $\begin{array}{r}\text { Storage capacity } \\
\text { range }(\mathrm{mm})\end{array}$ & Trendline Equations \\
\hline E. grandis & $0.33-0.65$ & $S_{\mathrm{c}}=1.525 x^{-0.29}$ \\
A. mearnsii & $0.77-1.44$ & $S_{\mathrm{c}}=0.659 x^{-0.28}$ \\
P. patula & $0.55-0.98$ & $S_{\mathrm{c}}=0.981 x^{-0.32}$ \\
\hline
\end{tabular}

Calder (1986) and Hall (2003). Due to the lower kinetic energy of low-intensity rainfall events, the raindrops are able to settle on the leaves and branches. Conversely, high-intensity events are normally characterised by larger raindrops with greater kinetic energy as well as turbulent conditions which are able to "dislodge" the raindrops from the canopy, thereby not allowing as much precipitation to settle. This does not necessarily mean that the interception will be lower for highintensity events, as the wet canopy evaporation may be high during these events. What can also be seen in Fig. 7 is that there was little change in storage capacity at rainfall intensities greater than 3 to $4 \mathrm{~mm} \mathrm{~h}^{-1}$ for Pinus patula and Acacia mearnsii, whereas the storage capacity does not change much after 1 to $2 \mathrm{~mm} \mathrm{~h}^{-1}$ for Eucalyptus grandis. These findings also highlight the importance of the water holding characteristics of the canopy due to leaf texture and leaf orientation. This is most evident by considering E. grandis, which has the largest LAI but the smallest canopy storage capacity due to its smooth, "waxy" leaves that repel water effectively as well as the angle at which the leaves hang. The canopy storage capacity range and the trendline equations are shown in Table 4 , where $S_{\mathrm{c}}$ is the storage capacity and $x$ is the rainfall intensity $\left(\mathrm{mm} \mathrm{h}^{-1}\right)$. The storage capacities and equations in Table 4 are site-specific and therefore should not be extrapolated to other areas, as these values will change depending on the LAI.

To further emphasise the importance of fully understanding the role that rainfall amount, intensity, duration and fre-
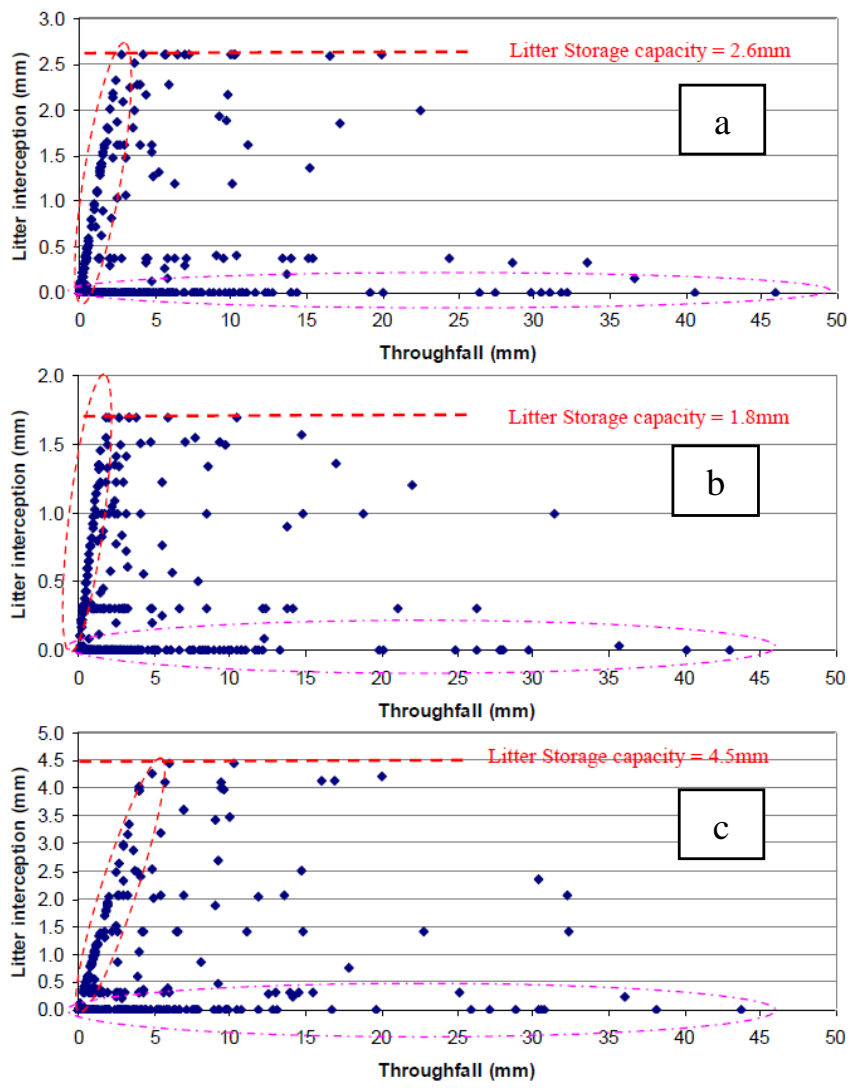

Fig. 8. Observed litter interception by (a) Eucalyptus grandis, (b) Acacia mearnsii, and (c) Pinus patula at Two Streams. The red circle represents increasing litter interception with increasing throughfall.

quency play in canopy interception, two contrasting periods of February 2009 and February 2010 are shown in Table 5.

Although there was a large difference in the rainfall during these two periods, there was not a large difference in the number of events. Due to the larger rainfall events of higher intensity in February 2009, the canopy interception expressed as a percentage of gross precipitation is far lower 
Table 5. Observed canopy interception by E. grandis, A. mearnsii and P. patula for the two contrasting periods of February 2009 and 2010.

\begin{tabular}{lrrrrrrrrr}
\hline \multirow{2}{*}{$\begin{array}{l}\text { Time } \\
\text { period }\end{array}$} & \begin{tabular}{c} 
Gross \\
precipitation \\
\cline { 3 - 7 }
\end{tabular} & $(\mathrm{mm})$ & $(\mathrm{mm})$ & $(\%)$ & $(\mathrm{mm})$ & $(\%)$ & $(\mathrm{mm})$ & $(\%)$ & \\
\hline February 2009 & 216.4 & 21.5 & 9.9 & 39.4 & 18.2 & 31.2 & 14.4 & 21 \\
February 2010 & 43.0 & 9.1 & 21.2 & 13.5 & 31.4 & 11.1 & 25.8 & 17 \\
\hline
\end{tabular}
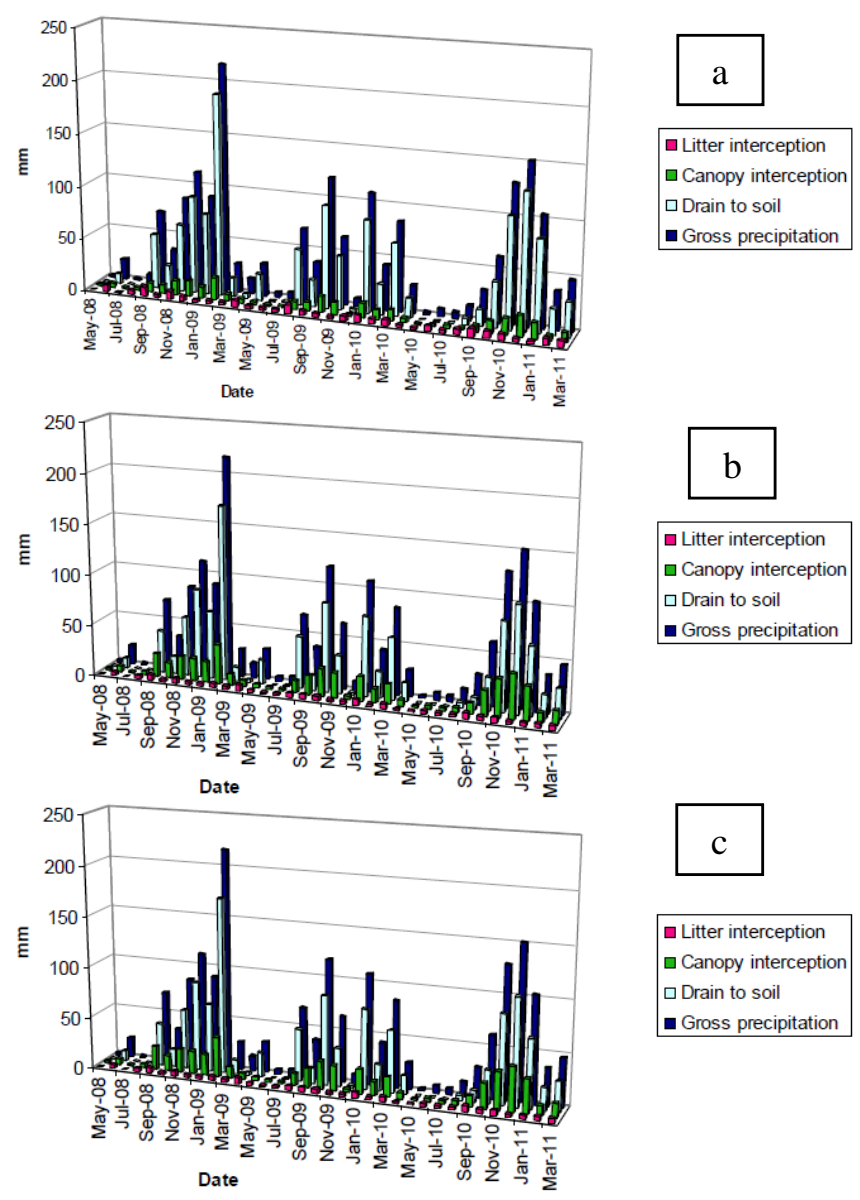

Table 6. Observed litter interception by E. grandis, A. mearnsii and P. patula from April 2008 to March 2011.

\begin{tabular}{lrrr}
\hline & $\begin{array}{r}\text { Gross } \\
\text { precipitation } \\
(\mathrm{mm})\end{array}$ & $\begin{array}{r}\text { Observed } \\
\text { litter } \\
\text { interception } \\
(\mathrm{mm})\end{array}$ & $\begin{array}{r}\text { Observed } \\
\text { litter }\end{array}$ \\
\hline E. grandis & 1884.7 & 160.4 & 8.5 \\
A. mearnsii & 1884.7 & 124.7 & 6.6 \\
P. patula & 1909.7 & 231.2 & 12.1 \\
\hline
\end{tabular}

portions of gross precipitation that are lost due to canopy and litter interception. The remaining water that is not intercepted and drains to the soil is summarised in Table 7.

Figure $8 \mathrm{a}, \mathrm{b}$ and $\mathrm{c}$ shows the litter interception relative to the throughfall for E. grandis, A. mearnsii and P. Patula respectively. The circled values closest to the y-axis represent the increasing litter interception with increasing throughfall. These are events that are smaller than the antecedent litter moisture deficit, and where almost $100 \%$ of the throughfall is intercepted. This happens until the point where the litter becomes saturated and maximum storage capacity is reached. Once the storage capacity has been reached, any additional throughfall will drain to the soil. The maximum litter storage capacities for E. grandis, A. mearnsii and P. patula are $2.6 \mathrm{~mm}, 1.8 \mathrm{~mm}$ and $4.5 \mathrm{~mm}$ respectively. The storage capacity is illustrated by the horizontal broken red line and was determined by analysing the data for events that occurred after a long dry period, when the litter was completely dry, and resulted in water draining out of the bottom of the litter interception basins (i.e. water that drained to the soil). The values circled along the $\mathrm{x}$-axis are events that take place after the litter has been saturated (i.e. the storage capacity has been reached) and almost none of the throughfall is intercepted. The values scattered in between the two sets of circled values are events that exceed the antecedent litter moisture deficit, but where the litter is not completely dry, so the litter interception value will only be as large as the litter moisture deficit. Table 6 shows the total litter interception for E. grandis, A. mearnsii and P. patula during the study period. The litter interception results reported in this study may be slightly too high due to the potential errors reported in Sect. 2.6.1.
The results of the litter interception study are illustrated in Fig. 8a, b and c. Figure 9a, b and c illustrates the relative 
Table 7. Amount of water that drains to the soil for the study period April 2008 to March 2011 for E. grandis, A. mearnsii and P. patula.

\begin{tabular}{lrrrrr}
\hline & $\begin{array}{r}\text { Gross } \\
\text { precipitation } \\
(\mathrm{mm})\end{array}$ & $\begin{array}{r}\text { Observed } \\
\text { water drained } \\
\text { to soil } \\
(\mathrm{mm})\end{array}$ & $\begin{array}{r}\text { Observed } \\
\text { water drained } \\
\text { to soil } \\
(\%)\end{array}$ & $\begin{array}{r}\text { Observed } \\
\text { canopy } \\
\text { interception } \\
(\%)\end{array}$ & $\begin{array}{r}\text { Observed } \\
\text { interception } \\
(\%)\end{array}$ \\
\hline E. grandis & 1884.7 & 1437.0 & 76.2 & 14.9 & 8.5 \\
A. mearnsii & 1884.7 & 1237.7 & 65.7 & 27.7 & 6.6 \\
P. patula & 1909.7 & 1269.8 & 66.5 & 21.4 & 12.1 \\
\hline
\end{tabular}

\subsection{Relative contributions of canopy and litter interception and water that drains to the soil}

Figure $9 \mathrm{a}, \mathrm{b}$ and $\mathrm{c}$ illustrate the relative proportions of monthly gross precipitation that is intercepted by the canopy and litter as well as how much water drains to the soil (net precipitation) per month.

From Fig. 9a, b and c, the three summer rainfall seasons over which this study took place can be identified, with February 2009 being the month with the highest rainfall of $216.4 \mathrm{~mm}$. The relative portions of canopy and litter interception to gross precipitation and therefore the amount of water that drains to the soil are dependant on the rainfall distribution. During the summer months, more water drains to the soil than is intercepted (canopy + litter). Conversely, during the winter months when there is little rainfall, there is often more rainfall intercepted than drains to the soil. The rainfall that does fall during the winter months is usually lowintensity frontal rainfall and not a large amount, resulting in a large proportion being intercepted by the canopy and litter. During the winter months, the litter often has time to dry out due to the extended periods of no rainfall, which results in a greater ability for the litter to intercept that which is not intercepted by the canopy during subsequent events. This will determine the amount of water that is available to drain to the soil. The total amount of water that drains to the soil during the study period is summarised in Table 7.

After canopy and litter interception have taken place, the remaining water drains to the soil (net precipitation). From Table 7 it can be seen that only $65.7 \%$ and $66.5 \%$ of gross precipitation reached the soil under the A. mearnsii and $P$. patula stands, respectively. Eucalyptus grandis has the lowest combined interception losses and $76.2 \%$ of the gross precipitation reached the soil.

\section{Discussion and conclusion}

This study showed that interception plays a very important role in the forest hydrological cycle, with only $66.5 \%$ to $76.2 \%$ of gross precipitation being available water that drains to the soil, after the losses due to canopy and litter interception. Canopy interception by E. grandis, A. mearnsii and P. patula accounted for losses of $14.9 \%, 27.7 \%$ and
$21.4 \%$ of gross precipitation, respectively. Although litter interception resulted in a smaller portion of the total interception loss, it is nonetheless important. In this study it was found that litter interception accounted for a loss of $12.1 \%$ of gross precipitation by $P$. patula, and $8.5 \%$ and $6.6 \%$ for $E$. grandis and A. mearnsii, respectively. Gerrits (2010) found litter interception to be as high as $22 \%$ in a beech forest and $18 \%$ in a needle leaf litter Cedar forest, while Helvey (1964) found litter interception to be $34 \%$ in a poplar stand in the USA. Interception not only reduces net precipitation but it is also a threshold process, as a certain amount of water is required before successive processes such as infiltration and runoff can take place. This is evident in the litter interception results as shown by the circled values closest to the y-axis, which represent the increasing litter interception with increasing throughfall. These are events that are smaller than antecedent litter moisture deficit, and only once this litter moisture content exceeds the storage capacity of the litter can subsequent processes such as infiltration take place. Although the storage capacity of the litter is much greater than that of the canopy, canopy interception is greater. This highlights that the evaporative potential of the canopy is far greater than that of the forest floor litter due to its direct exposure to solar radiation and wind.

One implication of interception being a threshold process is that it causes a delay in the onset of subsequent processes, particularly infiltration (Gerrits, 2010). This delay may be a few seconds to minutes in cases where both the canopy and litter are nearly saturated or in high-intensity storms. Conversely, this delay may be in the order of days to weeks in cases where the next rainfall event is not large enough to exceed the canopy and litter storage capacities, and therefore only after an event large enough to satisfy the combined storage capacities of the canopy and litter will subsequent processes take place. This is evident in Fig. 8a, b and c, where there are many events where the throughfall did not exceed the litter storage capacity and therefore no infiltration took place. This delay is also not the same for all species.

As interception reduces and delays subsequent hydrological processes differently for all species, it also determines the spatial distribution of net precipitation. Within a commercially afforested catchment such as the Mistley-Canema estate, there are many species and types of vegetation and 
thus different canopy and litter interception characteristics. The spatial distribution of net precipitation is not only different between stands but also within the stand. It is for this reason that linear troughs were used to measure throughfall, as the throughfall varies from near the trunk to the edge of the canopy, depending on the structure and water holding characteristics of the canopy. Within a commercial plantation, the spacing and management of the trees will also affect the spatial distribution of throughfall. Therefore, interception plays a far more significant and complex role in a catchment water balance than just as a reducer of rainfall.

As the study site is situated in a mist belt area, where more than $50 \%$ of the daily rainfall events are less than $1 \mathrm{~mm}$, it is not surprising that the interception losses are high. As shown in Fig. 7, the rainfall intensity affects the canopy storage capacity and should not be considered as a constant. The canopy properties such as "wettability" and leaf angle also affect the water retention and therefore canopy storage capacity. Although the E. grandis had the largest LAI, it has the lowest storage capacity. The rainfall amount, duration, frequency and intensity also play an important role in determining the canopy interception as shown in Table 5. It is therefore recommended that further research into canopy and litter interception be undertaken in other bioclimatic regions where rainfall patterns may differ. Furthermore, it can be seen from the results of this study that canopy and litter interception play a significant role in the water balance of a forested catchment and should not be ignored for water resources planning purposes. To account for canopy and litter interception loss for water resources planning, models that are not data-intensive and that can make use of readily available data would improve and aid in decision making. The findings from this study could therefore be used in improving and verifying canopy and litter interception models.

Acknowledgements. The authors wish to thank the Miriam Coenders-Geritts and the anonymous reviewer for their valuable and constructive comments.

Edited by: D. Mazvimavi

\section{References}

Bosch, J. M. and Hewlett, J. D.: A review of catchment experiments to determine the effects of vegetationchanges on water yield and evapotranspiration, J. Hydrol., 55, 3-23, 1982.

Calder, I. T.: A stochastic model of rainfall interception, J. Hydrol., 89, 65-71, 1986.

Camp, K. G. T.: The bioresources groups of KwaZulu-Natal. Cedara Report N/A/97/6, KwaZulu-Natal Department of Agriculture, Pietermaritzburg, South Africa, 1997.

Clulow, A. D.: The long-term measurement of total evaporation over Acacia mearnsii using large aperture scintillometry, Unpublished MSc dissertation, School of Environmental Science, University of KwaZulu-Natal, Pietermaritzburg, RSA, 2007.
Crockford, R. H. and Richardson, D. P.: Partitioning of rainfall in a eucalyptus forest and pine plantation in southeastern Australia: II. Stemflow and factors affecting stemflow in a dry sclerophylleucalypt forest and a Pinus radiata plantation, Hydrol. Process., 4, 145-155, 1990.

Crockford, R. H. and Richardson, D. P.: Partitioning of rainfall into throughfall, stemflow and interception: effect of forest type, ground cover and climate, Hydrol. Process., 14, 2903-2920, 2000.

Cuartus, L. A., Tomasella, J., Nobre, A. D., Hodnett, M. G., Waterloo, M. J., and Múnera, J. C.: Interception water-partitioning dynamics for a pristine rainforest in Central Amazonia: Marked differences between normal and dry years, Agr. Forest Meteorol., 145, 69-83, 2007.

Davis Instruments.: Rain collector, Hayward, CA, United States of America, 2001.

David, J., Valente, F., and Gash, J. H. C.: Evaporation of intercepted rainfall, in: Encyclopedia of Hydrological Science, edited by: Anderson, M. G., 43, 627-634, John Wiley \& Sons, Ltd, West Sussex, England, 2005.

Dye, P. J. and Versfeld, D. B.: Rainfall interception by a ten year old Pinus patula plantation. Unpublished contract report to Department of Water Affairs and Forestry, FOR-DEA 424, Division of Forest Science and Technology, CSIR, Sabie, South Africa, 1992.

Everson, C., Moodley, M., Gush, M., Jarmain, C., Govender, M., and Dye, P.: Can effective management of riparian zone vegetation significantly reduce the cost of catchment management and enable greater productivity of land resources, Water Research Commission, Pretoria, South Africa, Report K5/1284, 2006.

Gash, J. H. C., Wright, I. R., and Lloyd, C. R.: Comparative estimates of interception loss from three coniferous forests in Great Britain, J. Hydrol., 48, 89-105, 1980.

Gerrits, A. M. J.: The role of interception in the hydrological cycle, VSSD, Delft, The Netherlands, 2010.

Gerrits, A. M. J., Savenije, H. H. G., Hoffmann, L., and Pfister, L.: Measuring forest floor interception in a beech forest in Luxembourg, Hydrol. Earth Syst. Sci. Discuss., 3, 2323-2341, doi:10.5194/hessd-3-2323-2006, 2006.

Godsmark, R.: The South African Forestry and Forest Products Industry 2007, http://www.forestry.co.za/statistical-data/ (last access: 11 May 2009), 2008.

Gower, S. T. and Norman, J. M.: Rapid estimation of leaf area index in forests using the LI-COR LAI-2000, Ecology, 72, 1896-1900, 1990.

Hall, R. L.: Interception loss as a function of rainfall and forest types: stochastic modelling for tropical canopies revisited, J. Hydrol., 280, 1-12, 2003.

Helvey, J. D.: Rainfall interception by hardwood forest litter in the southern Appalachians, US Forest Services Research Paper SE, $8,1-8,1964$

Helvey, J. D. and Patric, J. H.: Canopy and litter interception of rainfall by hardwoods of the eastern United States, Water Resour. Res., 1, 193-206, 1965.

Jacobsz, M. G.: Rainfall interception by forest litter. Unpublished BSc thesis, Department of Agricultural Engineering, University of Natal, Pietermaritzburg, South Africa, 1987.

Jewitt, G. P. W.: Process studies for the simulation modelling of forest hydrological processes, Unpublished MSc dissertation, 
Department of Agricultural Engineering, University of Natal, Pietermaritzburg, South Africa, 1991.

Klaasens, W., Bosveld, F., and de Water, E.: Water storage and evaporation constituents of rainfall interception, J. Hydrol., 212-213, 36-50, 1998.

Langford, K. J. and O'Shaughnessy, P. J.: A study of canopy interception in native forests and conifer plantations, Melbourne and Metropolitan Board of Works, Australia, Report No., MMBWW-0007.88, 1978.

Llorens, P. and Gallart, F.: A simplified method for forest water storage capacity measurement, J. Hydrol., 240, 131-144, 2000.

Llorens, P., Poch, R., Latron, J., and Gallart, F.: Rainfall interception by a Pinus sylvestris forest patch overgrown in a Mediterranean mountainous abandoned area I. Monitoring design and results down to the event scale, J. Hydrol., 199, 331-345, 1997.

Mucina, L. and Rutherford, M. C.: The vegetation of South Africa, Lesotho and Swaziland, Strelitzia 19, South African National Biodiversity Institute, Pretoria, South Africa, 2006.

Onset Computer Corporation.: HOBO pendant event/temperature data logger, Bourne, MA, United States of America, 2005.

Park, H.-T., Hattori, S., and Tanaka, T.: Development of a numerical model for evaluating the effect of the litter layer on evaporation, J. Forest Res., 3, 25-33, 1998.
Samraj, P., Haldorai, B., and Henry, C.: Conservation forestry, in: 25 years research on soil \& water conservation in southern hilly high rainfall regions, Monograph no.4 of Central Soil and Water Conservation Research \& Training Institute, Dehra Dun-248, India, 195, 153-199, 1982.

Schaap, M. G. and Bouten, W.: Forest floor evaporation in a dense Douglas fir stand, J. Hydrol., 193, 97-113, 1997.

Schulze, R. E., Scott-Shaw, C. R., and Nanni, U. W.: Interception by Pinus patula in relation to rainfall parameters, J. Hydrol., 36, 393-396, 1978.

Tsiko, C. T., Makurira, H., Gerrits, A. M. J., and Savenije, H. H. G.: Measuring forest floor and canopy interception in a savannah ecosystem, Phys. Chem. Earth., 47, 122-127, 2012.

Versfeld, D. B.: Predictive models for rainfall interception - measurements in Pinus radiata and Protea neriifolia, South African National Committee of the International Association of Hydrological Sciences Symposium, Grahamstown, South Africa, 1987.

Zwolinski, J. and Bayley, A. D.: Research on planting stock and forest regeneration in South Africa, New Forest, 22, 59-74, 2001. 